\title{
Distribution of glacial geomorphic features on the Antarctic continental shelf and correlation with substrate: implications for ice behavior
}

\author{
J. S. Wellner, A. L. Lowe, S. S. Shipp, J. B. Anderson \\ Department of Earth Science, Rice University, Houston, Texas 77005, U.S.A.
}

\begin{abstract}
Surveys were conducted seaward of all the major drainage outlets of the Antarctic ice sheet from the Pennell Coast, northVictoria Land, to Marguerite Bay, Antarctic Peninsula. The results show that the ice sheet extended onto the outer shelf. Glacial troughs occur offshore of all major glacial outlets. Where the substrate is crystalline bedrock, ice flow tended to follow the structural grain of the bedrock, deposited little sediment and eroded the underlying bedrock. Where ice flowed over relatively soft, more easily eroded, sedimentary strata, the direction of ice flow was more directly offshore, and depositional features characterize the sea-floor. In these areas the signature of the grounded ice consists of till deposits and large-scale geomorphic features. Drumlins occur within the region of contact between crystalline and sedimentary substrates. The different geological substrates are interpreted to have exerted a fundamental control on the behavior of past ice sheets. The troughs in the areas of bedrock composed of sedimentary substrate are interpreted to have been occupied by relatively fast-flowing ice, ice streams, and the troughs in the areas of crystalline substrate are interpreted to have been occupied by slower-moving ice. The area between these two zones was characterized by ice acceleration and is marked by drumlins.
\end{abstract}

\section{INTRODUCTION}

Currently much attention is focused on sea-level rise and the potential for ice-sheet collapse. Ice streams have been cited as the potential weak link that could lead to this collapse (e.g. Hughes, 1973). Ice streams account for the majority of ice discharge from the West Antarctic ice sheet (WAIS) (Bentley, 1987) and they influence the behavior and stability of ice sheets by providing a means for rapid discharge from the interior of the ice sheet.

Field measurements indicate that neighboring West Antarctic ice streams vary widely in behavior (Shabtaie and Bentley, 1987; Whillans and others, 1987), and satellite observations have recorded significant changes in activity (Bindschadler and Vornberger, 1998; Rignot, 1998). Studies of the WAIS indicate that irregular ice-stream behavior is, in large part, controlled by subglacial bed conditions and processes occurring at and within the bed (Alley and others, 1986, 1987; Blankenship and others, 1986, 1987, 2001; Rooney and others, 1987; Alley, 1989; Engelhardt and Kamb, 1991; Anandakrishnan and others, 1998; Bell and others, 1998; Tulaczyk and others, 1998). Troughs in the underlying topography may delineate ice-stream margins, and a step in ice-surface topography typically marks the onset of streaming (Shabtaie and Bentley, 1987). Aerogeophysical imaging (Bell and others, 1998) and seismic profiling (Anandakrishnan and others, 1998) indicate that the area of Ice Stream B, which flows into the Ross Ice Shelf (Fig. 1), coincides with a geologic boundary between a sedimentary basin and crystalline bedrock. Anandakrishnan and others (1998) and Bell and others (1998) asserted that a transition from crystalline bedrock to softer sediments is necessary for onset of streaming to occur. Drilling at an upstream portion of Ice Stream B (Fig. 1) recovered a weak, unconsolidated sediment layer located at the base of the streaming ice (Engelhardt and others, 1990; Englelhardt and Kamb, 1991; Kamb, 1991). Detailed examination of weak tills retrieved from Ice Stream B determined that the till formed from recycled poorly indurated sediments. Therefore, movement of ice streams via a deforming-till layer may be controlled by locations of sediment sources (Tulaczyk and others, 1998).

Despite great interest in the connection between subglacial geology and ice behavior, there remains much to be learned from field observations. The Antarctic continental shelf, previously covered by expanded ice sheets, contains a relatively undisturbed record of subglacial conditions that is more accessible than the current subglacial environment.

This paper presents geophysical and sedimentological observations from the continental shelf offshore of each of the major ice-drainage outlets between north Victoria Land and the Antarctic Peninsula (Fig. 1). All major drainage outlets of the WAIS are included, except those of the Weddell Sea. In addition, drainage areas of the East Antarctic ice sheet (Pennell Coast and western Ross Sea) and the Peninsula Ice Cap (Marguerite Bay) are included. The research focused on the large glacial troughs that occur in each drainage area. The dataset includes seismic imaging of the substrate over which the ice flowed, high-resolution seismic imaging of the upper bed, multibeam swath bathymetry imaging of large geomorphic features on the shelf, deep-tow side-scan sonar imaging of smaller bedforms, and geological sampling of the bed. Relationships between 
a.

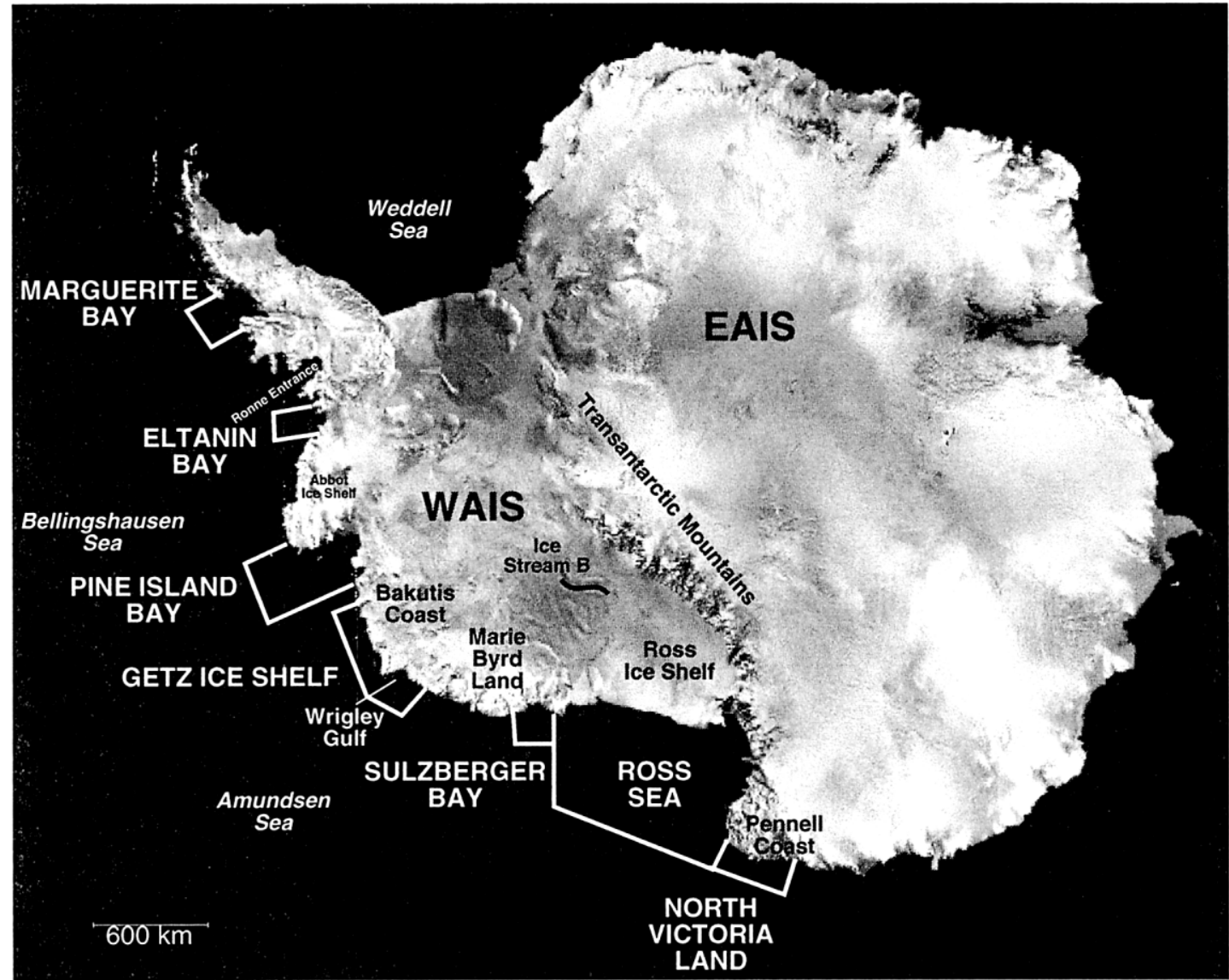

b.
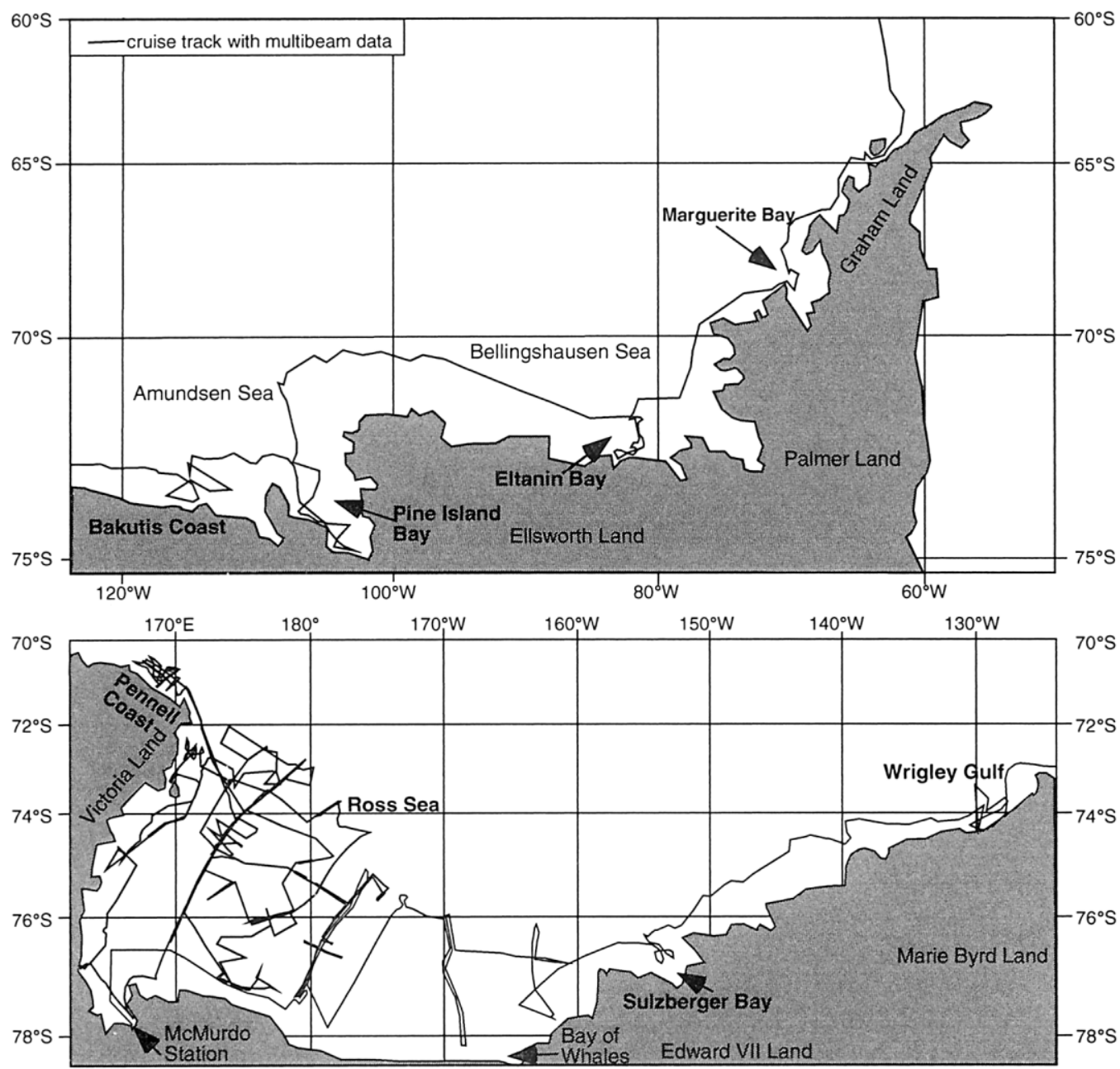

Fig. 1. (a) Satellite image of Antarctica with study areas marked. EAIS, East Antarctic ice sheet; WAIS, West Antarctic ice sheet. AVHRR image from http://TerraWeb.wr.usgs.gov/TRS/projects/Antarctica/color/index.html. (b) Distribution of data used in this study. Black lines mark positions of cruise tracks. Multibeam data and $3.5 \mathrm{kHz}$ data were collected for all of each cruise. 
geomorphic features and substrate geology were observed. These correlations have implications for the control that the substrate geology may exert on ice behavior.

\section{METHODS}

The majority of the data used in this study were collected aboard the RV/IB Nathaniel B. Palmer during the 1998 and 1999 seasons (cruises NBP9801 and NBP9902). Our analysis of individual drainage outlets followed a systematic approach whereby seismic records, swath bathymetry data and sediment cores were acquired along the axis of troughs. Data between troughs were collected primarily in transit. The seismic data were collected with either a $50 \mathrm{in}^{3}$ $\left(820 \mathrm{~cm}^{3}\right)$ or a $210 \mathrm{in}^{3}\left(3442 \mathrm{~cm}^{3}\right)$ generator-injector air gun and a single-channel streamer. The data were recorded with an Elics seismic acquisition system. The seismic data were band-pass filtered. The vertical resolution of these data is on the order of $10 \mathrm{~m}$. The $3.5 \mathrm{kHz}$ data are higher-resolution, but do not penetrate beyond $\sim 10 \mathrm{~m}$. The $3.5 \mathrm{kHz}$ data were not processed. The multibeam swath bathymetry data were collected with a SeaBeam 2100 hull-mounted system and consist of 120 beams of $12 \mathrm{kHz}$ data. Data editing removed anomalous beams. Processing included applying a corrected sound-velocity profile, and gridding and displaying the data in shaded-relief maps. Grid size varied for each image based on the water depth and area included in the image; an average grid size is about $30 \mathrm{~m}$ by $30 \mathrm{~m}$. Vertical resolution of the multibeam data is on the order of a few meters. The Datasonics deep-tow side-scan sonar images finer-scale bathymetric features. These data were not processed. The geological dataset consists of piston cores that penetrated to a maximum of $8.15 \mathrm{~m}$ and kasten (gravity) cores that are up to $2.5 \mathrm{~m}$ long.

Substrate differentiation was based on seismic facies descriptions and consisted largely of determining if the sub- crop in each area is crystalline or sedimentary. Continuous to semi-continuous parallel to divergent seismic reflections, which onlap landward onto more chaotic seismic units, represent sedimentary substrates. Chaotic and discontinuous reflection patterns were interpreted as crystalline substrates. This seismic reflection pattern also can represent a diamicton. The two are distinguishable because till and glacial-marine diamictons form a thin deposit packaged with marine strata and rest on an erosional unconformity, whereas the basal contact is not observed in crystalline bedrock where there is generally much greater relief. In addition, sedimentary strata of different ages onlap crystalline basement rocks. Onshore outcrops also were used to help interpret the observed seismic units.

Glacial landforms were identified and divided into categories of depositional, erosional or mixed based on mode of formation (Table 1; Fig. 2). Table 2 presents sedimentary units identified in cores and seismic profiles. Analysis of the data followed Anderson's (1999) summary of sedimentological and seismic criteria for defining deposits that occur on the Antarctic continental shelf and his description of geomorphic features imaged by side-scan sonar and multibeam techniques.

\section{RESULTS}

\section{North Victoria Land shelf}

The Pennell Coast is located west of the Ross Sea in north Victoria Land, where the Transantarctic Mountains meet the coast (Fig. 1). In contrast to the other areas in this study, drainage along the Pennell Coast is wholly within East Antarctica. The continental shelf, relative to the other regions in this study, is very narrow (Fig. 3a). Rugged bathymetry and crystalline substrate, similar to the onshore portion of the study area, characterizes the inner shelf (Fig. 3b) (Brake and Anderson, 1983). Multibeam data from the inner shelf show steep troughs and erosional grooves. A

Table 1. Summary of geomorphic features identified in this study

\begin{tabular}{ccc}
\hline Landform & Definition \\
reference
\end{tabular}

Depositional features

Mega-scale glacial lineations

Erosional features

Grooves

Roches moutonnées

Glacial troughs

Gullies

Meltwater channels

Intermediate features

Drumlins
Large flutes, up to $70 \mathrm{~km}$ long, that are thought to form in deforming-till layers and represent rapidly flowing ice (C. D. Clark, 1993, 1994).

Irregular lineations in bedrock formed by scouring particles embedded in ice (Smith, 1948). They are orienated parallel to each other and indicative of ice-flow direction.

Asymmetric bedrock bumps or hills with abraded stoss faces and quarried lee faces (Carol, 1947). They range in size from meters to several hundreds of meters across.

Large canyon-like depressions carved by ice flow. Troughs can be hundreds of kilometers long and tens of kilometers wide and hundreds of meters deep. When formed in crystalline bedrock they tend to have narrow, deep, steep-sided U-shaped profiles and follow the structural grain. In sedimentary substrates, they are shallower and broader.

Submarine valleys carved in the continental slope by underflows of debris-rich meltwater from ice grounded at the shelf break (Anderson, 1999).

Channel forms cut by glacial meltwater. These are erosional features cut into bedrock and consolidated sediments by subglacial drainage.

Fig. 2c

Fig. 2b

Fig. 2b

Fig. 2b

Fig. 2a

Fig. 2d

Fig. 2e

Smooth, oval-shaped hills resembling a spoon along its long axis with the steep end pointing in the up-ice direction and the gentler, sloping end facing the down-ice direction (Menzies, 1979). Drumlins may form around crystalline or sedimentary bedrock irregularities and in that sense are erosional. They may also form by the deposition and erosion of glacial sediments.

Notes: This study uses a wide range of geomorphic features to interpret glacial history and basal conditions. The features can be grouped on the basis of whether they form in depositional zones, erosional zones or both. 

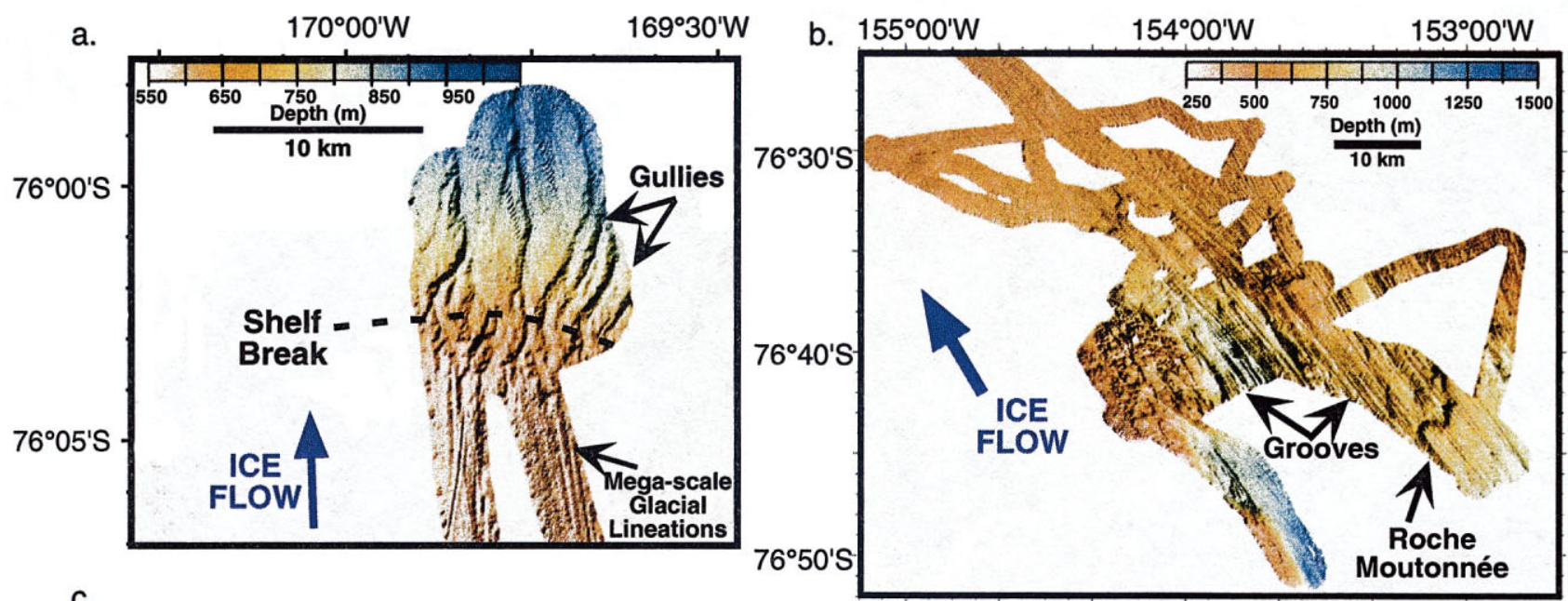

c.
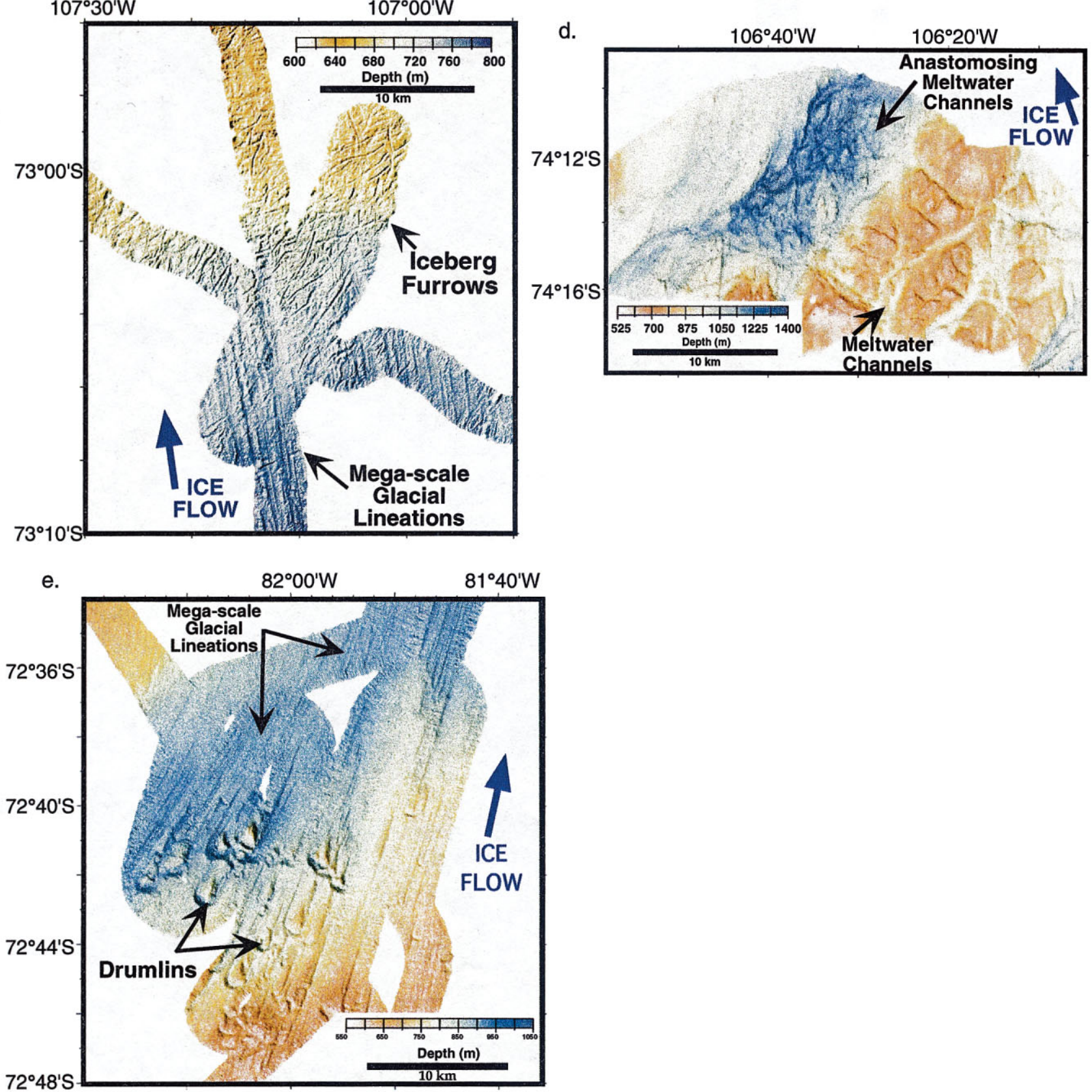

Fig. 2. Multibeam swath bathymetry: (a) Central Ross Sea showing gullies at the shelf break; (b) Sulzberger Bay showing the trough carved by grounded ice and the associated erosional grooves and roches moutonnées; (c) Pine Island Bay showing megascale glacial lineations that become overlain by an iceberg-furrowed sediment wedge further offshore; (d) Pine Island Bay showing meltwater channels; and (e) Eltanin Bay showing drumlins. See Table 1 for further discussion of geomorphic features, and Figure 1 for locations. The multibeam data have a vertical resolution of a few meters. Two of these images are modified from Anderson and Shipp (2001). 
Lodgement till

Deformation till

Pelletized unit

Sub-ice-shelf (transitional) and compound glacial -marine sediment

Diatomaceous mud/ooze
Diamicton with shear strengths $>0.5 \mathrm{~kg} \mathrm{~cm}^{-2}$ formed in the subglacial environment by sediment plastering onto the substrate through pressure-melting processes (Dreimanis, 1989; Lundqvist, 1989a).

Diamicton formed in a subglacial deforming layer (Benn and Evans, 1998). Deformation till is characterized by a wide-range of shear strengths, typically greater than associated glacial-marine sediment and less than lodgement till (usually $0.2-$ $0.5 \mathrm{~kg} \mathrm{~cm}^{-2}$ ) (Anderson, 1999).

Granulated sandy facies characterized by pellets or balls of sediment grains and agglutinated foraminifera. This unit occurs just above diamicton and below a muddy unit and is believed to be a grounding-line feature (O'Brien and Harris, 1996; Domack and others, 1998, 1999).

Includes a range of sediement types, from silts to diamictons formed beneath an ice shelf or on the open shelf (Anderson, 1999). They typically have lower shear strengths and more varied mineralogical content than associated tills and are characterized by occurrences of fossils (Anderson, 1999). X-ray analysis does not show a preferred clast orientation.

Identified by its olive-green color. Where this unit occurs it is always the surficial unit. Its maximum thickness is not known, but in some areas it is $>8 \mathrm{~m}$ thick. Diatomaceous mud contains $10-30 \%$ diatoms, and ooze contains $>30 \%$ diatoms.

Notes: Shear strengths reported in this paper are a factor of 10 lower than values reported in some sources. It appears that these older values were taken directly from the Torvane dial without applying the appropriate correction factor.

narrow sedimentary wedge occurs on the outer shelf (Fig. $3 \mathrm{c}$ ); no lineations were observed on the outer shelf. Piston cores collected from the trough flanks contain diamicton overlain by a thin pelletized unit (Table 2) and topped by diatomaceous deposits with varying amounts of ice-rafted debris. The basal diamicton is interpreted as till based on its occurrence below the pelletized unit, moderate shear strengths, lack of pebble fabric visible on X-ray and lack of pristine microfossils. The presence of till in piston cores indicates that the ice sheet grounded on the shelf. Limited multibeam data collected seaward of the shelf break indicate the presence of gullies.

\section{Ross Sea}

The Ross Sea, located between the Pennell Coast and Sulzberger Bay, is bound on the western margin by the Transantarctic Mountains, to the south by the Ross Ice Shelf and to the east by Marie Byrd Land (Fig. 1). The Ross Sea receives drainage from both the East and West Antarctic ice sheets. The continental shelf, wide relative to the rest of the study regions, is geographically divided into western, central and eastern sectors. Broad glacial troughs characterize the continental shelf. These troughs, occupied by paleo-ice streams over several glaciations, trend northeast-southwest (Hughes, 1977; Anderson, 1999; Shipp and others, 1999).

On the basis of seismic data, the continental-shelf substrate is predominantly seaward-dipping sedimentary strata. Deep Sea Drilling Project (DSDP) site 270 recovered Early Paleozoic marble and gneiss close to the sea-floor on the inner shelf of the central Ross Sea (Hayes and Frakes, 1975). Just south of the DSDP 270 site, the innermost central shelf has crystalline bedrock at the sea-floor, based on interpretations of seismic data. Excluding the innermost western and central Ross Sea shelves, unlithified sedimentary wedges and till sheets overlie the lithified sedimentary substrate. Geomorphic features, in addition to core data, have been used to define the extent of ice during the Last Glacial Maximum (LGM). In the western Ross Sea, ice extended to the outer shelf but did not reach the shelf edge (Licht and others, 1996; Domack and others, 1999; Shipp and others, 1999). Ice in the central and eastern Ross Sea extended to the continentalshelf edge (Domack and others, 1999; Licht, 1999; Shipp and others, 1999). Multibeam data show mega-scale glacial lineations within troughs. Drumlins occur on the inner shelf of the central Ross Sea, in association with the transition from crystalline to sedimentary substrate (Fig. 4). Subcrops of sedimentary strata characterize the innermost western Ross Sea shelf. Side-scan sonar and sub-bottom profiler data reveal thin, patchy deposits overlying an erosional surface in this region (Shipp and others, 1999).

Cores from the Ross Sea typically recovered diatomaceous mud overlying a soft diamicton with moderate numbers of microfossils. The latter is interpreted as an ice-shelf facies. A thin pelletized unit locally marks the base of the iceshelf facies (Domack and others, 1999). Below the pelletized unit or directly below the ice-shelf facies is till. The transition between the ice-shelf facies and the till is variably marked by an increase in shear strengths, color change and decrease in microfossil abundance. Locally, cores sampled a stiff diamicton, interpreted as lodgement till, underlying the sequence (Anderson and others, 1980; Shipp and others, 1999). Radiocarbon ages indicate that these strata were deposited during and since the last glaciation (Licht and others, 1996; Domack and others, 1999; Licht, 1999). In the western Ross Sea, lodgement till occurs on the innermost shelf in association with the thin, patchy deposits overlying the eroded sedimentary substrate. Softer diamictons occur in association with mega-scale glacial lineations (Domack and others, 1999; Shipp and others, 1999).

\section{Sulzberger Bay}

Sulzberger Bay, located east of the Ross Sea (Fig. 1), is bounded by the Edward VII Peninsula. A prominent trough appears aligned with the structural grain of the Marie Byrd Land coast. Multibeam data collected from the region show an irregular sea-floor characterized by erosional grooves (Fig. 2b). Seismic data acquired during previous cruises indicate that the bay is floored by crystalline bedrock (L. R. Bartek, seismic data, February 1999). Based on the extent of the trough and glacial grooves, it is apparent that the WAIS extended to the shelf break during a previous glacial cycle. Depositional geomorphic features (Table 1) were not observed.

Attempts during 1999 to core in this area largely were unsuccessful and yielded only bagged samples of sand and gravel. Several cores were obtained in Sulzberger Bay during a 1983 expedition (Deep Freeze 83). A core from inner Sulzberger Trough penetrated a light-olive-brown pebbly mud 

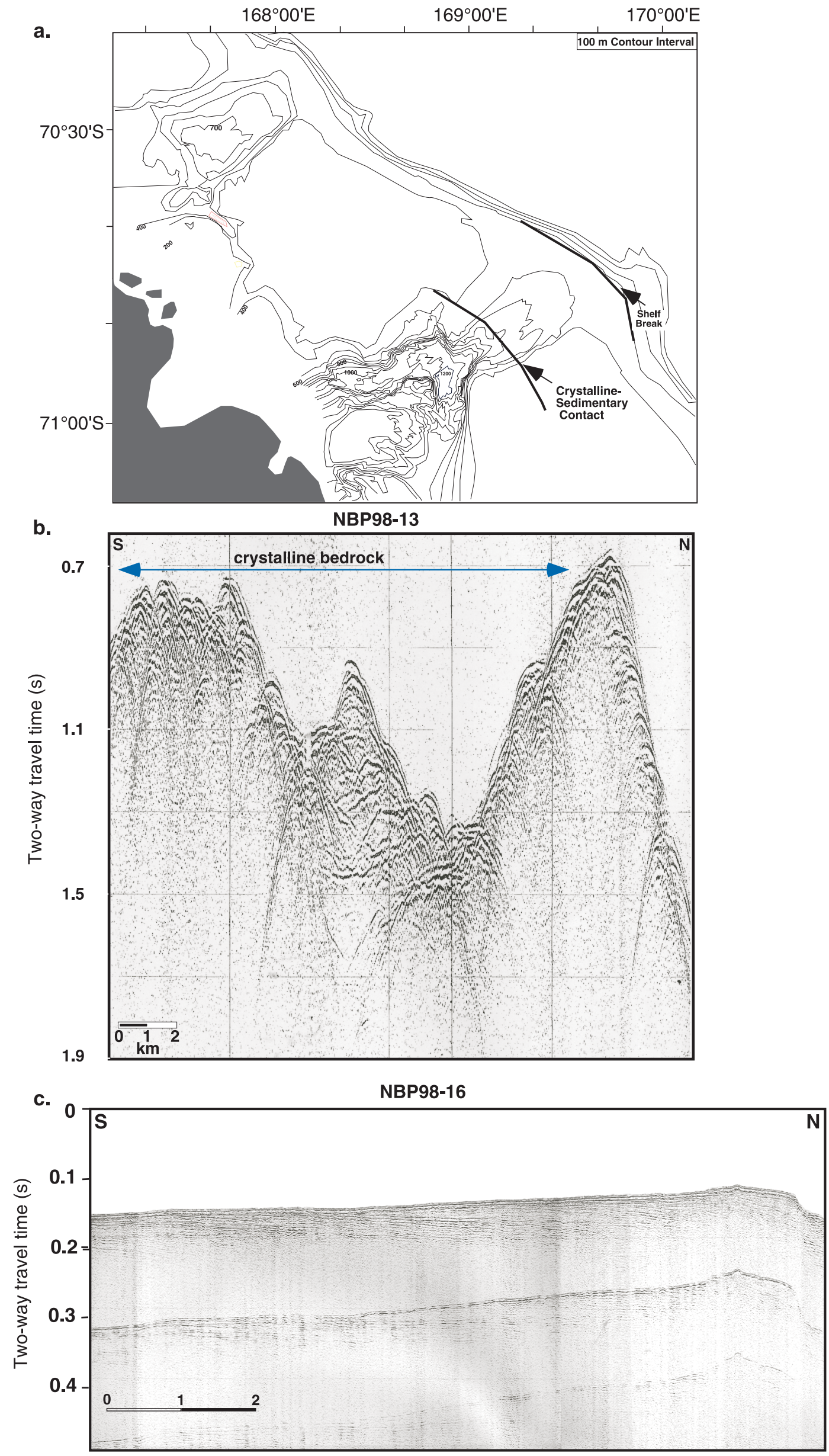

Fig. 3. (a) Bathymetric map of the continental shelf offshore of the Pennell Coast region showing the steep, narrow trough on the inner shelf that grades into a broad trough on the outer shelf. The distance between the crystalline-sedimentary contact and the shelf break is narrow, $35 \mathrm{~km}$, compared to other areas. Contour interval is $100 \mathrm{~m}$. (b, c) $50 \mathrm{in}^{3}$ air-gun seismic line (b) from the inner shelf showing the crystalline basement and (c) from the outer shelf showing progradational sediments. Locations are shown in ( $a)$. 


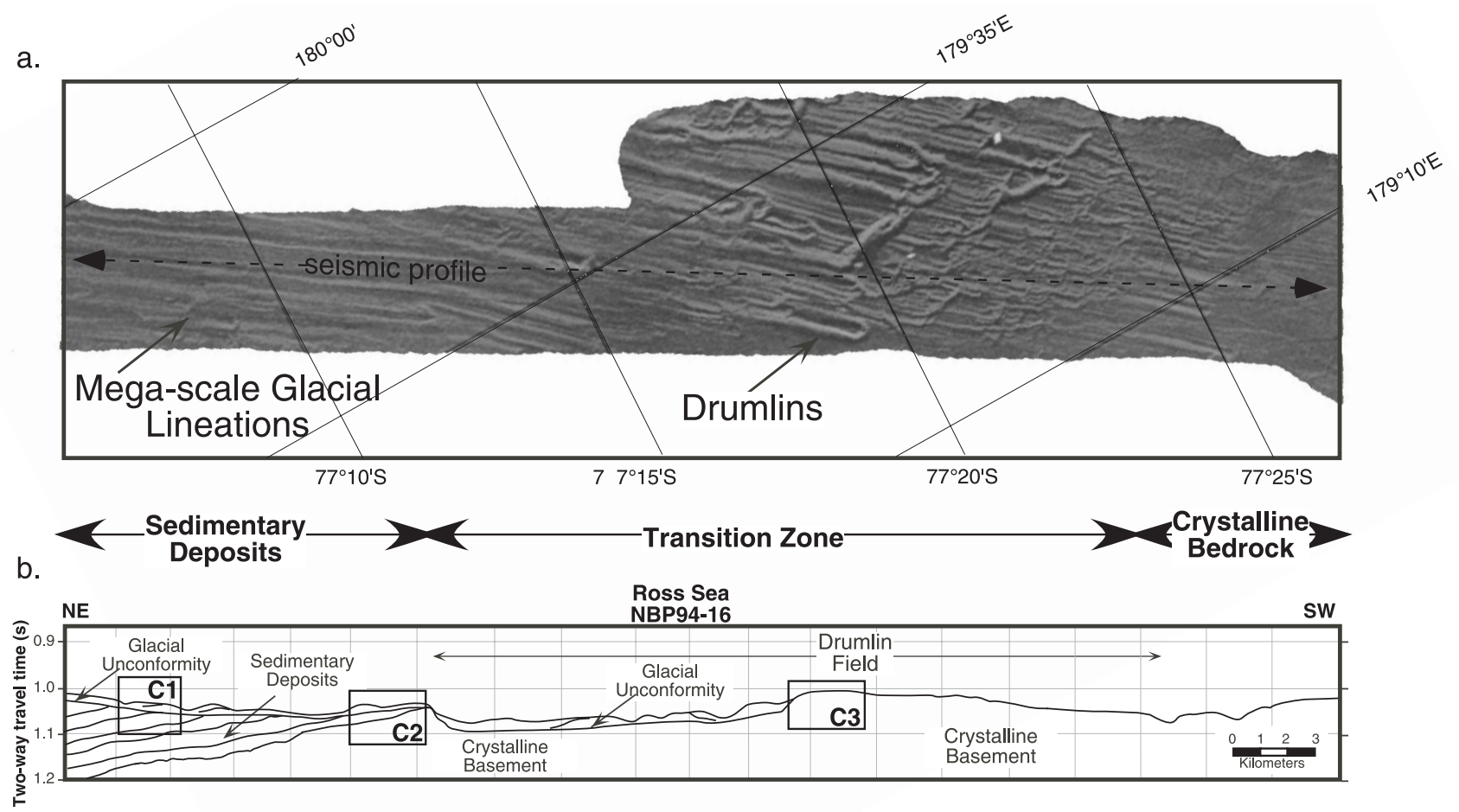

C.
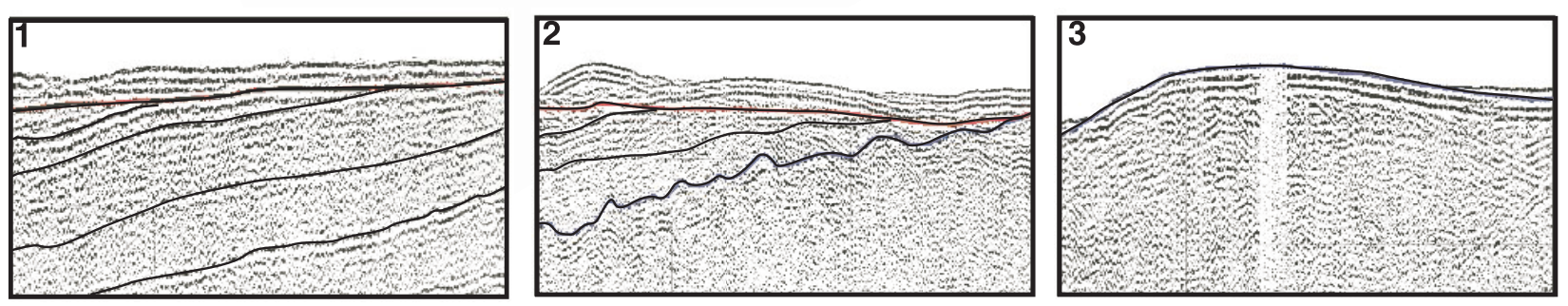

Fig. 4. (a) Drumlins in the transition zone in paleo-ice stream 3 in the central Ross Sea shown on swath bathymetry data. Darker shades of gray indicate shallower depths, and lighter shades of gray indicate greater depths. (b) Line drawing of a full seismic profile showing substrates upon which features in (a) formed. Crystalline bedrock occurs on the inner shelf, and seaward-dipping strata occur farther offshore. The drumlin field occurs near the contact between crystalline and sedimentary substrates. (c) Seismic data showing three substrate zones in detail. C1 is seaward-dipping strata, C2 shows strata onlapping onto crystalline bedrock, and C3 shows smooth crystalline bedrock on inner shelf.

(Cassidy, 1984). A core from the outer trough penetrated a light-olive-gray mud with few pebbles (Cassidy, 1984). Shear strength was not measured on either core. However, both cores were significantly deformed and washed in the liner, implying that stiff material, which often serves to plug the core, was not penetrated.

\section{Getz Ice Shelf (Wrigley Gulf and Bakutis Coast)}

Ice streams of the Getz Ice Shelf region currently flow around a group of small islands into Wrigley Gulf and across Bakutis Coast (Fig. 1). Large troughs occur in both of these regions (Fig. 5a). Multibeam data from both troughs show subglacial geomorphic features extending across the shelf, indicating that the WAIS grounded in locations currently at water depths of $>1000 \mathrm{~m}$. The data record erosional grooves on the inner shelf, and mega-scale glacial lineations extending across the outer shelf (Fig. 5b). On the inner shelf the troughs are aligned with the structural grain of the area. On the outer shelf, the troughs are oriented more directly offshore. Seismic data from the Bakutis Coast (Fig. 5c) show crystalline bedrock on the inner shelf. The outer shelf is characterized by seaward-dipping sedimentary strata, which toplap against an unconformity. The relief of the sea-floor on the inner shelf where older strata are exposed suggests that the strata are heavily lithified (Fig. 5c).

InWrigley Gulf and the Bakutis Coast region the transition between the crystalline and sedimentary substrate is delineated by a change from grooves to mega-scale glacial lineations (Fig. 5). Drumlins occur at the crystalline--sedimentary bed transition. Piston cores from the area of mega-scale glacial lineations sampled gray to olive-gray diamicton characterized by low shear strengths $\left(0.22-0.24 \mathrm{~kg} \mathrm{~cm}^{-2}\right)$. These deposits are interpreted to be deformation till, based on their stratigraphic relationships, shear strengths, X-ray character and low abundance of microfossils. Overlying the till are thin deposits of gray to brown diamicton with lower shear strengths than the till; this is interpreted to be glacial-marine sediment. Cores from the area of crystalline bedrock sampled dark-gray diamicton with shear strengths of $0.1-0.19 \mathrm{~kg} \mathrm{~cm}^{-2}$. These sediments are interpreted as glacial-marine deposits, primarily based on the abundance of microfossils.

\section{Pine Island Bay}

Pine Island Bay (Fig. 1) serves as catchment to a major convergent drainage system of the WAIS. Several deep and narrow troughs emerge from the coast (Fig. 6). These converge on the middle shelf to form one main trough that 
a.

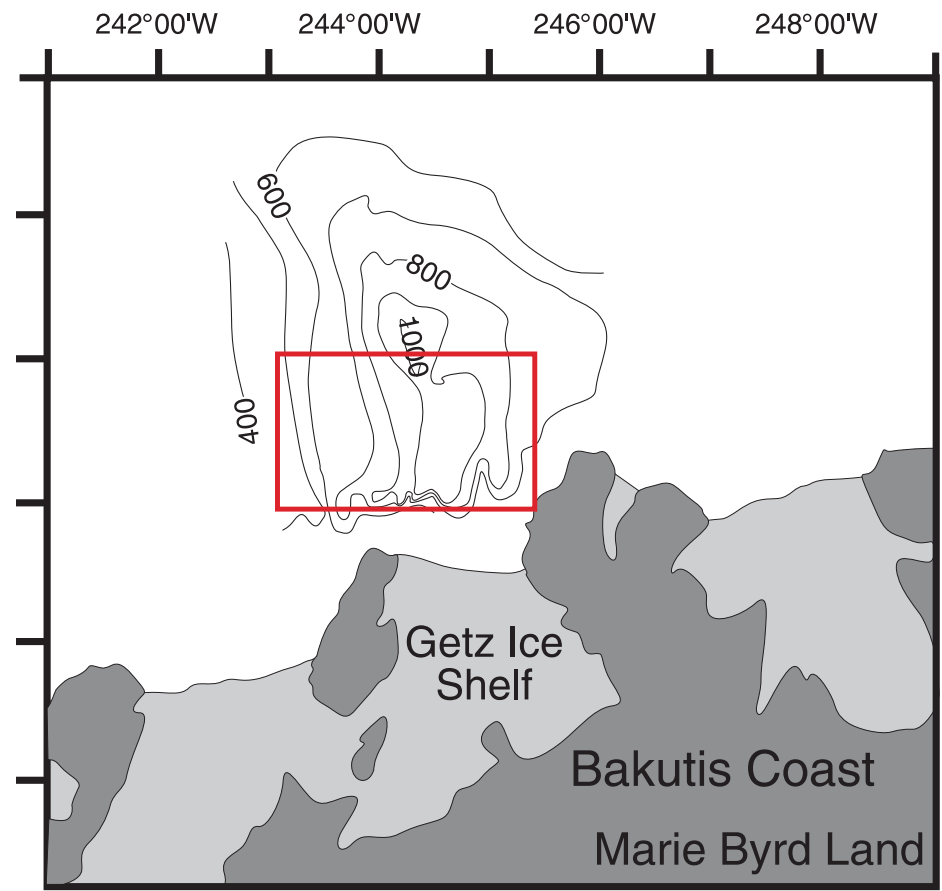

b.

$243^{\circ} 00^{\prime} \mathrm{W}$

$244^{\circ} 00^{\prime} \mathrm{W}$

$245^{\circ} 00^{\prime} \mathrm{W}$

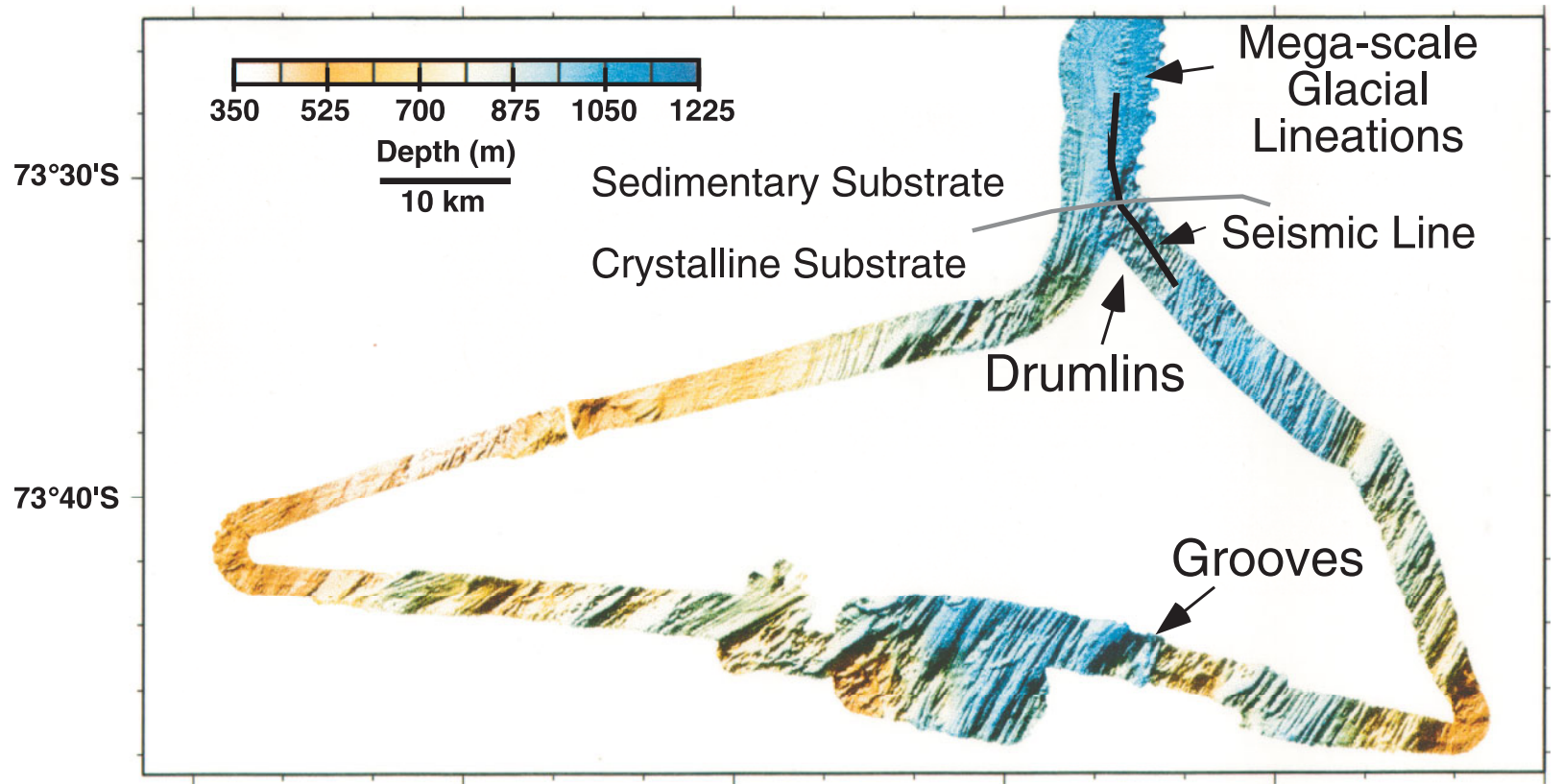

c.

NBP9902-10

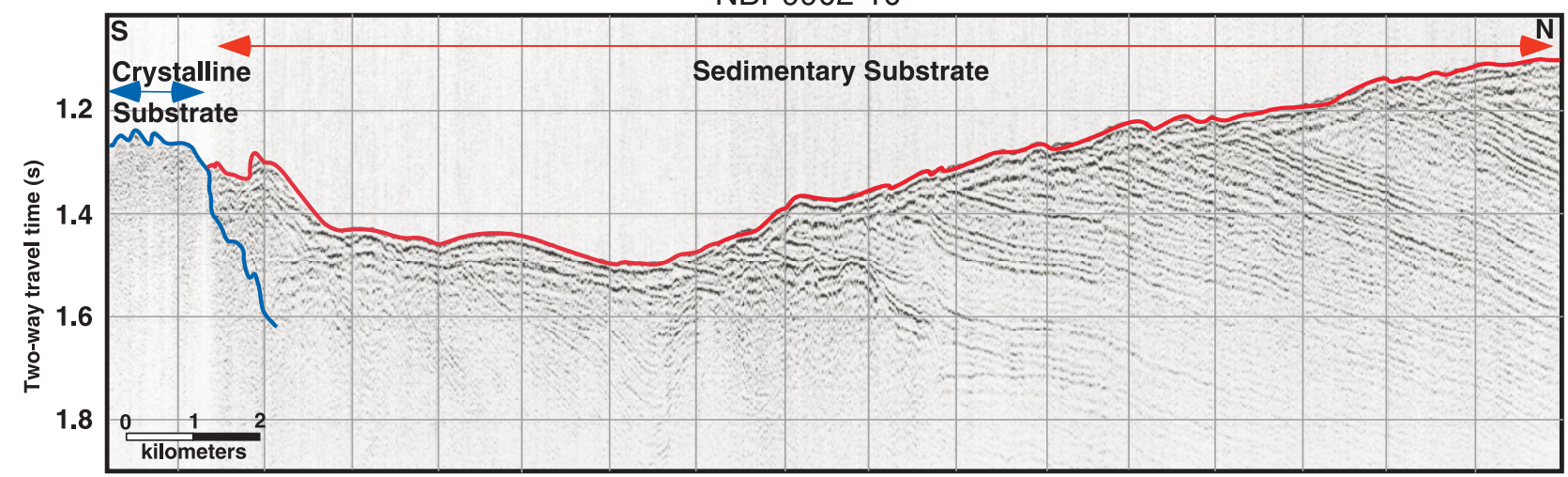

Fig. 5. (a) Location of paleo-glacial drainage trough offshore Bakutis Coast. Box shows area of (b). (b) Multibeam data and (c) seismic data from offshore of a portion of Getz Ice Shelf showing the change from crystalline to sedimentary substrate and the corresponding change in the geomorphic features on the shelf. Seismic location is shown on multibeam data. 
a.
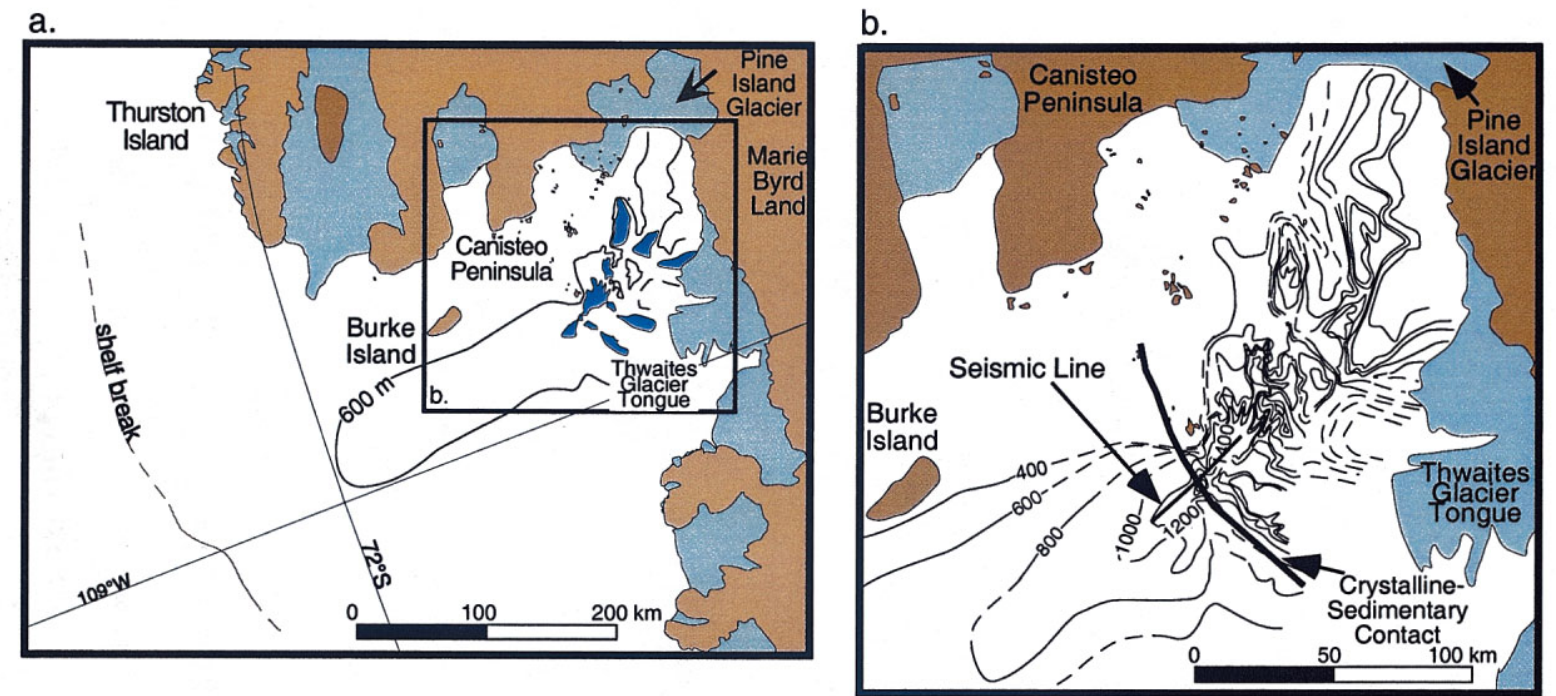

c.

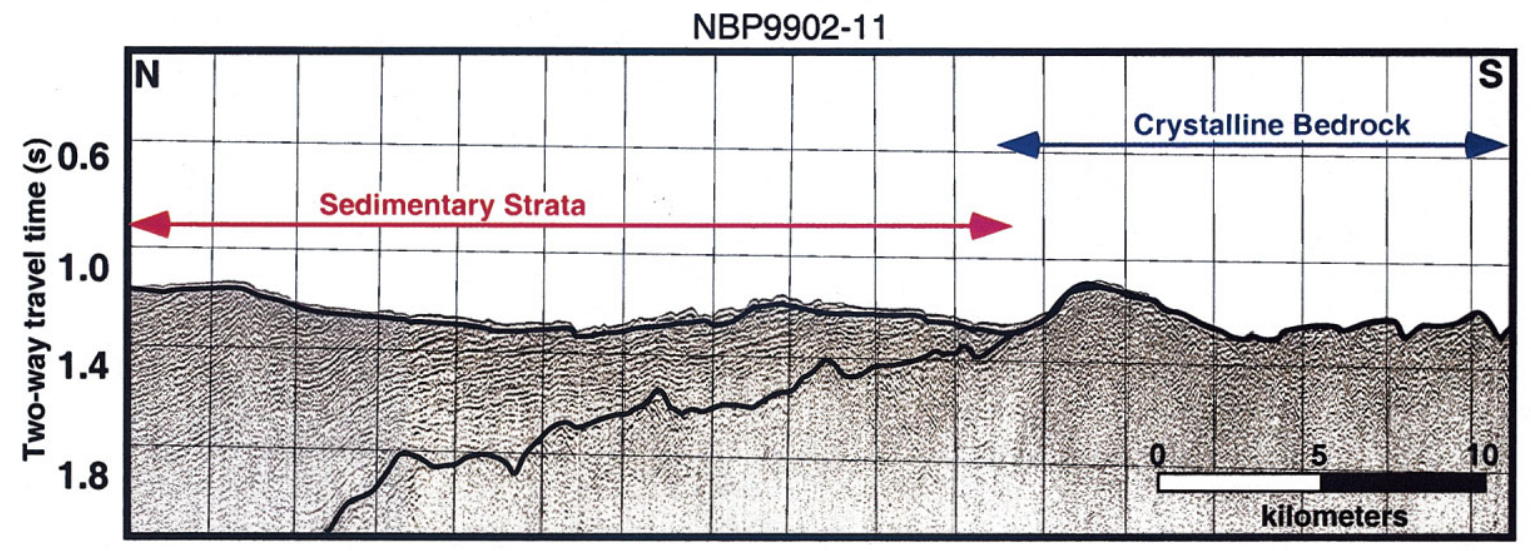

Fig. 6. (a) Location of paleo-glacial trough, marked with a $600 \mathrm{~m}$ contour line, in Pine Island Bay. Shaded areas within the trough represent areas deeper than $1400 \mathrm{~m}$. Location of $(b)$ is shown. (b) Detailed bathymetric map of Pine Island Bay showing the steep, narrow trough on the inner shelf and the broader shallower trough on the mid-outer shelf. Contour interval is $200 \mathrm{~m}$. (c) Seismic line from Pine Island Bay. Location is shown in ( $b$ ).

extends to the shelf break (Fig. 6b). The bathymetry of the continental shelf changes from a rugged inner shelf to a smooth outer shelf (Kellogg and Kellogg, 1987). The inner shelf displays relief with depths of 400-1700 m, while the outer shelf averages $500 \mathrm{~m}$ in depth. A seismic profile collected along the axis of the main trough reveals the transition in bathymetry corresponds to a change in substrate. An irregular crystalline bedrock surface characterizes the inner shelf and most of the middle shelf. Farther offshore, this surface dips below seaward-dipping strata, which toplap against an erosional surface at or near the sea-floor (Fig. 6c). North of Burke Island, a sedimentary wedge, composed of prograding sequences of chaotic and layered deposits, overlies these strata. The occurrence of this wedge and other deposits above the glacial unconformity creates the broad, smooth bathymetry common on the outer shelf.

Multibeam bathymetric images show channels on the rugged crystalline basement of the inner shelf, and the preliminary interpretation is that these features are meltwater channels (Fig. 2d). Glacial erosional features include grooves and gouges. Drumlins occur just landward of the contact between crystalline bedrock and sedimentary substrate. Cores from the inner shelf are short, but sampled alternating units of diamicton with low shear strengths $\left(<0.1 \mathrm{~kg} \mathrm{~cm}^{-2}\right)$ and clay. This is interpreted to be a sub-iceshelf unit. Within the deeper portions of the trough on the outer shelf, mega-scale glacial lineations are present (Fig. 2c). In locations shallower than $700 \mathrm{~m}$ depth, such as the younger sedimentary wedge, iceberg furrows obliterate the lineated surface (Fig. 2c). Gullies occur on the continental shelf offshore of Pine Island Bay.

\section{Eltanin Bay}

Eltanin Bay (Fig. 1) is a broad bay located in the Bellingshausen Sea west of the Abbot Ice Shelf and east of the Ronne Entrance. In the LGM reconstruction of Denton and Hughes (1981), Eltanin Bay receives drainage from a large area of Ellsworth Land. Multibeam data reveal a large trough extending across the shelf. The data show erosional grooves in the inner portion of the bay. Farther offshore, mega-scale glacial lineations characterize the geomorphology. No data were collected from the outer shelf due to severe weather conditions. A drumlin field separates the zones of erosional grooves and mega-scale glacial lineations (Fig. 2e). Individual drumlins are 5-10 km long. The multibeam data suggest there may be channel-like depressions around the heads of the drumlins, indicating that formation of the drumlins may have included pressure melting and water flow around the drumlins. Multibeam data show that the WAIS grounded where water depths are currently up to $1200 \mathrm{~m}$ on the middle shelf, although the grounding line probably was seaward of the data coverage. Piston cores collected from the middle shelf sampled till, with shear 
strengths of $<0.34 \mathrm{~kg} \mathrm{~cm}^{-2}$, beneath thin units of very soft diamicton with greater abundance of microfossils. The area of diamicton is coincident with the area of mega-scale glacial lineations.

\section{Marguerite Bay}

Marguerite Bay is the most northern drainage area surveyed in this study; it is located north of Alexander Island at the southern end of the Antarctic Peninsula. It receives drainage from the Antarctic Peninsula Ice Cap. A deep trough, >1650 m, occupies the inner shelf of Marguerite Bay and extends seaward across the shelf (Pope and Anderson, 1992). The innershelf seismic data from this region are not from the same location as the multibeam data. However, the seismic data available do show basement rocks and folded forearc rocks at the sea-floor (Bart and Anderson, 2000). Based on these seismic data and comparison of the multibeam data to data in other areas, the substrate in the inner shelf is interpreted to be crystalline bedrock with highly irregular topography. Grooves occur on the trough floor. Steep slopes, especially on the western flank, mark the trough boundaries. A drumlin field lies farther seaward. Seismic profiles collected offshore of the drumlin region show smooth middle and outer shelves floored by prograding seaward-dipping strata (Bart and Anderson, 1995), and sampling at ODP site 1079 recovered lithified sediments (Barker and others, 1998).

Cores collected from the eastern portion of the bay sampled thick muds with ice-rafted debris and a moderate number of microfossils, underlain by sediment-gravity-flow deposits (Kennedy and Anderson, 1989). Cores from the western region sampled thin glacial-marine units underlain by transitional glacial-marine deposits, or in rare cases, thick sections of stiff till occurring in water depths of $>700 \mathrm{~m}$ (Kennedy and Anderson, 1989). A single core collected from within the drumlin field sampled glacialmarine sediment underlain by sediment-gravity-flow deposits.

\section{Correlation between geomorphic features and geological substrate}

In each of the study areas, large glacial troughs were mapped on the continental shelf offshore of major drainage outlets. The troughs vary in size and extent across the study areas. However, their general shapes and bathymetry are similar, in that they are narrower and deeper on the inner shelf over crystalline bedrock and broader and shallower on the outer shelf where they cut sedimentary strata. This change in trough geometry, from narrow and deep to broad and shallow, partially may be controlled by the foredeepened nature of the Antarctic continental shelf, in that the troughs must broaden on the outer shelf to allow for somewhat constant volumes of ice.

Analysis of the data from across the region reveals a range of substrates on which former expanded ice sheets were grounded. Two end-members include slightly erodible crystalline bedrock and more easily eroded sedimentary strata. In locations where ice is interpreted to have flowed over both end-members, a transition zone between the two exists. Each substrate zone displays characteristic geomorphic features and sedimentary deposits that are consistent throughout the drainage areas.

\section{Crystalline bedrock}

The inner shelf of most study areas is characterized by crystalline bedrock with highly irregular bathymetry. Deep erosional grooves and steep-sided troughs are the dominant features (Fig. 2b). These features indicate the direction of ice flow, which appears to have followed the structural grain of the underlying bedrock, displaying sharp turns and an orientation that is not always directed offshore. The north Victoria Land (Fig. 3), Sulzberger Bay (Fig. 2b), Getz Ice Shelf (Fig. 5) and Pine Island Bay (Fig. 6) study areas are the main examples of these features. Other landforms associated with crystalline bedrock include meltwater channels such as those seen in Pine Island Bay (Fig. 2d), and roches moutonnées such as those seen in Sulzberger Bay (Fig. 2b). Erosional formation of the landforms may be controlled by either grounded ice (e.g. grooves and roches moutonnées) or by meltwater (e.g. incised channels) (Table 1).

\section{Sedimentary substrates}

Sedimentary strata that dip offshore characterize the outer shelf in most areas. Troughs widen and shallow as they extend across the softer substrate, and mega-scale glacial lineations are the dominant geomorphic feature. Mega-scale glacial lineations form in material eroded from the substrate. Individual lineations are tens of kilometers long and are about $0.4 \mathrm{~km}$ wide. Sets of lineations can be seen to deviate in orientation as ice is able to spread and the flow direction changes.

In general, as the ice sheet advanced across the continental shelf it sampled crystalline bedrock, lithified sedimentary strata and unlithified Plio-Pleistocene deposits. The extent of these geological domains varies from one area to the next.

Sedimentary substrates characterize most of the Ross Sea (Fig. 4) and the outer shelves of north Victoria Land, Wrigley Gulf and the Bakutis Coast (Fig. 5), Pine Island Bay (Fig. 6), Eltanin Bay (Fig. 2e) and Marguerite Bay. Sulzberger Bay is the only study area where no sedimentary substrate is known to exist. The north Victoria Land drainage area is the only area that has a sedimentary wedge not characterized by mega-scale glacial lineations. Elsewhere, lineations exist just seaward of the crystalline bedrock-sedimentary-strata contact. Thus, it appears that mega-scale glacial lineations can form on lithified sedimentary strata, as well as soft PlioPleistocene sediments.

The distribution of deformation till (Table 2) appears to correlate to the occurrence of mega-scale glacial lineations. This relationship previously has been documented in Antarctica in the Ross Sea (Licht, 1999; Shipp and others, 1999). In most study areas, cores collected from the region of mega-scale glacial lineations consist of glacial-marine deposits overlying relatively soft till. Variations include the eastern Ross Sea where lodgement till, in addition to soft till, is occasionally found in the region of mega-scale glacial lineations. Also, cores from areas such as bank margins between adjacent ice streams in the Ross Sea sampled deformation till, but lack associated geomorphic features. Few cores from the areas of crystalline substrate recovered diamicton. However, when diamicton is recovered in cores from areas of crystalline substrate, it is not significantly different from that in cores farther out on the shelf.

It is not possible from this dataset to accurately measure the thickness of the deforming bed in the different study areas. The complete thickness of till is at least as large as the amplitude of the mega-scale glacial lineations. These average 
about $15-20 \mathrm{~m}$ in height across the study areas. Seismic profiles from the Ross Sea image a distinct unit in which mega-scale glacial lineations occur that are $15-35 \mathrm{~m}$ thick (Shipp and others, 1999). Cores did not penetrate the bottom of this deposit. Hence, it is beyond the range of the data to determine whether the entire unit is deformed, or only its upper surface.

The extent of deformation till varies from basin to basin, but more data are needed to quantify its distribution. The minimum dimensions of such a deposit can be inferred by analyzing the extent of mega-scale glacial lineations and the distribution of deformation till sampled in cores. In the Ross Sea, where a sedimentary substrate floors most of the area, the area of lineations extends almost $200 \mathrm{~km}$ from the inner to the outer shelf. In those areas where multibeam data were collected across the troughs, mega-scale glacial lineations are imaged across the entire trough. Limited bathymetric data show no mega-scale glacial lineations in the area of the inter-ice-stream banks and boundary ridges in the Ross Sea (Shipp and others, 1999), but cores indicate deformation till is present.

\section{Transition zone}

A geomorphic transition zone occurs where the substrate changes from crystalline bedrock to sedimentary strata. The extent of this zone varies. It includes portions of the sea-floor seaward and landward of the point where strata begin to onlap onto the crystalline basement. Drumlins occur within the transition zone. Only one area, the north Victoria Land shelf, has crystalline and sedimentary substrates, but lacks drumlins within a transition zone.

Offshore Getz Ice Shelf, drumlin-like features occur landward of the crystalline--sedimentary substrate contact (Fig. 5). These drumlins have their heads in crystalline bedrock and grade seaward into thin onlapping sediments. Different types of drumlins include those in the central Ross Sea. These are rock-cored drumlins, with seismic data showing underlying bedrock highs serving as obstructions to ice flow (Fig. 4). In Eltanin Bay, drumlins are believed to be composed of sediment. Deep troughs surrounding the heads of the drumlins in Eltanin Bay may indicate erosion by water that flowed around the drumlins during their formation (Fig. 2e). Drumlins in Pine Island Bay display the same property, but these are bedrock drumlins formed in the crystalline portion of the transition zone.

\section{DISGUSSION}

Many studies have examined the role of subglacial geology in the behavior of Northern Hemisphere ice sheets (e.g. Alley, 1991; MacAyeal, 1993; Alley and MacAyeal, 1994). P. U. Clark (1994) proposed that subglacial bed conditions, not climate, caused rapid fluctuations in behavior of the Laurentide ice sheet. Boulton (1996) attributed large-scale till sequences formed by the North American, British and European ice sheets during the last glacial cycle to the process of subglacial sediment deformation over beds of unlithified sediments. Marshall and others (1996) used geologic and topographic data to model areas of potential fast flow in the Laurentide ice sheet and suggested that interior plains and the continental shelf, rather than the crystalline shield, favor ice-stream development. Patterson (1998) proposed that geology and topography beneath the Laurentide ice sheet exerted control on the areas of fast ice flow. Her results indicated that ice-covered sedimentary valleys contained thicker ice and reached the pressure-melting point before areas of positive relief. This mechanism facilitated faster flow. A geologic control on modern-day Antarctic ice streams has also been proposed (e.g. Anandakrishnan and others, 1998; Bell and others, 1998).

A consistent distribution of geomorphic features was observed in each of the drainage areas. A typical distribution includes erosional features such as grooves or roches moutonnées on the inner shelf, drumlins in the transition zone, mega-scale glacial lineations on the outer shelf, and gullies on the slope (Fig. 7a). This distribution pattern of geomorphic features correlates with changes in the substrate (Fig. 7). Additionally, the features observed on the continental shelf may be interpreted to reflect the behavior of the ice sheet that was grounded on the continental shelf. The crystalline, transition and sedimentary substrate zones are interpreted to represent three different conditions of ice flow (Fig. 7c). Table 3 summarizes the flow conditions in each zone.

A correlation between a deforming bed and streamlined bedforms has been made by several workers including C. D. Clark (1993, 1994), Hart and Smith (1997), Shipp and others (1999), Stokes and Clark (1999) and Canals and others (2000). On the Antarctic continental shelf, troughs in areas of sedimentary substrate have been interpreted as areas of convergent ice flow and streaming ice (Anderson, 1999). This is based on the configuration of the bathymetry, the concentration of sediment within portions of the troughs, and the lineated nature of the upper surface. The mega-scale

Table 3. Geomorphic features observed in this study and their interpretations

\begin{tabular}{|c|c|c|c|c|}
\hline Landform & Substrate & Inferred ice conditions & Example areas & $\begin{array}{l}\text { Figure } \\
\text { reference }\end{array}$ \\
\hline \multicolumn{5}{|l|}{ Depositional } \\
\hline Mega-scale glacial lineations & Sedimentary & Fast & Ross Sea, Getz, PIB, Eltanin Bay & Fig. 2c \\
\hline \multicolumn{5}{|l|}{ Erosional } \\
\hline Grooves & Crystalline & Slow & Pennell, Sulzberger, PIB, Getz & Fig. $2 b$ \\
\hline Roches moutonnées & Crystalline & Slow & PIB, Sulzberger & Fig. $2 b$ \\
\hline Meltwater channels & Crystalline & Slow & PIB & Fig. 2d \\
\hline Gullies & Sedimentary & $\begin{array}{l}\text { Meltwater, ice } \\
\text { at shelf break }\end{array}$ & $\begin{array}{l}\text { Western R.S., PIB, Pennell, } \\
\text { Sulzberger slopes }\end{array}$ & Fig. 2a \\
\hline \multicolumn{5}{|l|}{ Intermediate } \\
\hline Drumlins & Crystalline-sedimentary transition & Accelerating & $\begin{array}{l}\text { Central R.S., Getz, PIB, Eltanin, } \\
\text { Marguerite }\end{array}$ & Fig. $2 \mathrm{e}$ \\
\hline
\end{tabular}


a.

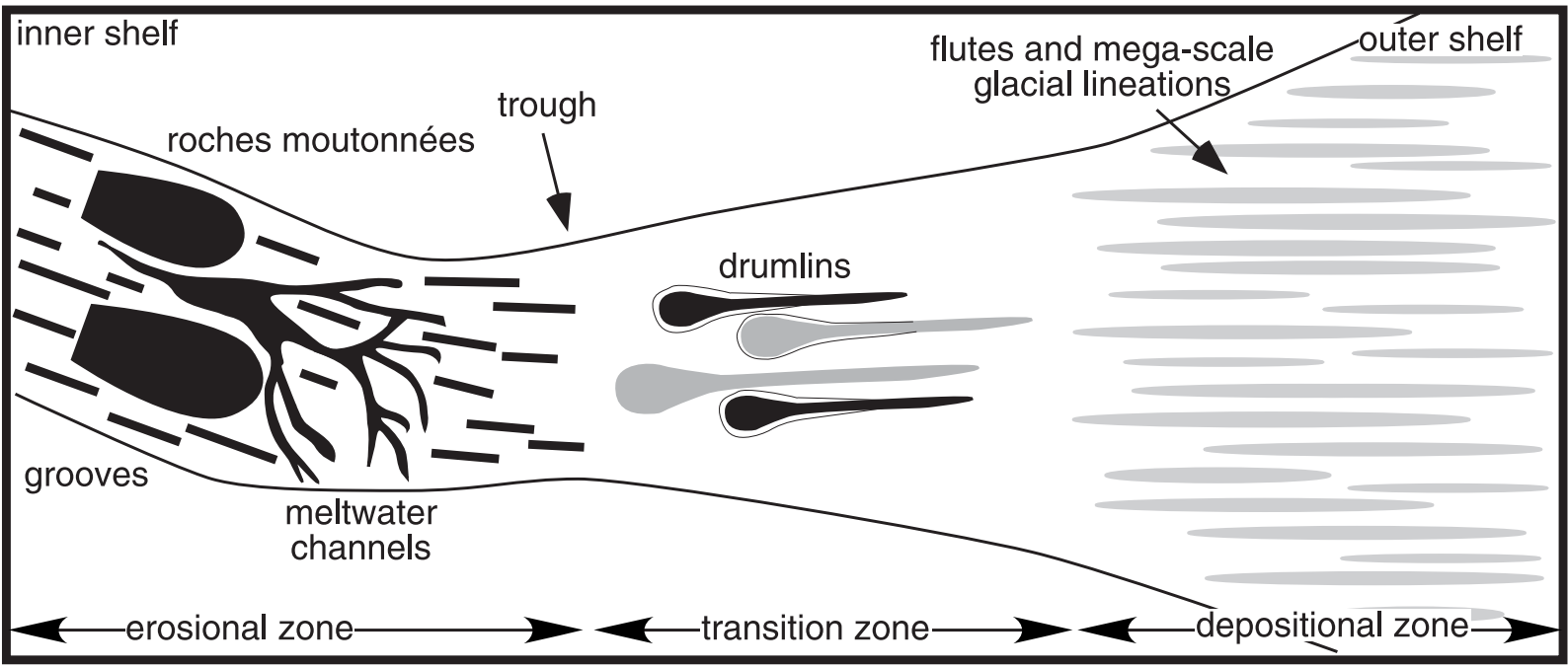

b.

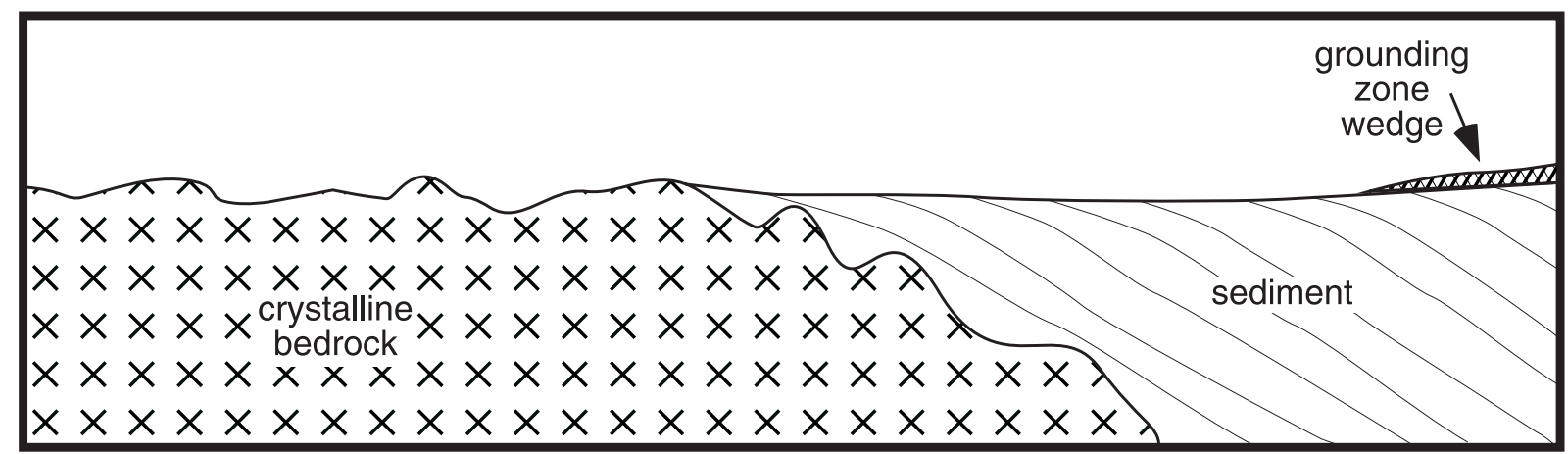

c.

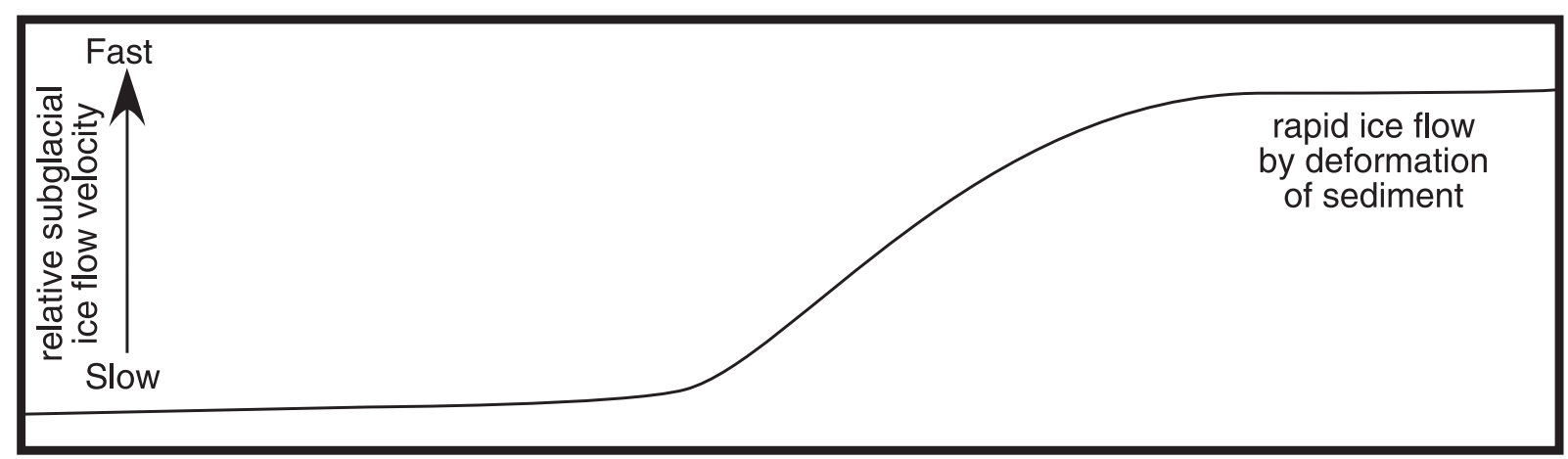

Fig. 7. Diagram summarizing the inferred relationship between geomorphic features, substrate and subglacial ice-flow velocity.

(a) Distribution of geomorphic features in plan view. Black represents areas of erosion, and gray represents areas of deposition.

(b) Corresponding change in substrate from the inner to outer shelf. (c) Relative speed of ice flow.

glacial lineations visible on multibeam swath bathymetry data have been interpreted as representing areas where ice was streaming (Shipp and others, 1999). Areas of mega-scale glacial lineations also have been correlated to deposits of soft diamicton (Domack and others, 1999; Shipp and others, 1999). Slower-moving ice is interpreted to have occupied banks, although no absolute rates are implied.

Flow over the crystalline substrate is thought to have been relatively slow and resulted in erosional geomorphic landforms. Flow over the sedimentary substrate, where there is a deforming bed, is interpreted to have been relatively fast. It is important to note that although the data show that a sedimentary substrate is required for the presence of mega-scale glacial lineations, there are areas of sedimentary substrate that do not have mega-scale glacial lineations, particularly the inner shelf of the western Ross Sea and the outer shelf of north Victoria Land, despite having supported grounded ice. Therefore, a sedimentary substrate is required for fast flow by bed deformation, but fast flow does not occur on all sedimentary substrates.
The transition zone spanning the crystalline--sedimentary substrate contact represents a zone of acceleration. Drumlins are the most prominent features within transition zones, including the central Ross Sea, Getz Ice Shelf, Pine Island Bay, Eltanin Bay and Marguerite Bay. The acceleration zone was an area of dynamic change in the ice sheet, and thus was also the area of maximum relief in the ice surface. Bell and others (1998) described an area of high relief in the ice surface at the modern-day onset of Ice Stream B.

All locations with crystalline substrate on the inner shelf and mega-scale glacial lineations on the outer shelf have drumlins in the transition zone. Drumlins were not observed in any other setting. Because drumlins occur between regions of slow ice flow over crystalline substrate and regions of fast flow over sedimentary substrate, they are interpreted to be indicative of acceleration. Mickelson and others (1983) and Attig and others (1989) suggested that drumlins formed in areas where the ice was partially frozen to the bed and locally thawed. This may be comparable to the association we have made between drumlins and ice 
acceleration. Drumlins also have been interpreted as forming in areas of extensional flow (Lundqvist, 1989b; Van der Wateren, 1995), but to our knowledge this study provides the first correlation between drumlins and the interpreted onset of streaming flow for Antarctic ice streams.

Meltwater also is interpreted as having played an important role in controlling ice behavior. The data indicate that the amount of meltwater present varies from basin to basin. Abundant channels in Pine Island Bay, which are interpreted as meltwater channels based on the morphological expression (Fig. 2d), represent the only evidence for meltwater on the inner part of the shelf. Drumlins occur seaward of the channels and show the influence of meltwater, with erosion occurring around the drumlin heads (Shaw, 1988; Shaw and others, 1989). Similarly, the drumlins in Eltanin Bay (Fig. 2e) and the Ross Sea (Fig. 4) appear to have channels, or moats, around their edges. These channels possibly were formed by localized flowing water. This water may have been caused by high stresses around the drumlin that resulted in locally high dissipation of mechanical energy to heat. As drumlins grade into mega-scale glacial lineations, this water was available to be incorporated into deforming till. Meltwater affected icestream dynamics until the ice reached deformable sediments on the shelf, where it became incorporated into the sediments to produce deforming till. No geomorphic features indicative of large amounts of meltwater were imaged on the sedimentary substrate. Because water must be incorporated into till to allow deformation to occur, free meltwater probably does not occur in areas of deforming till. Gullies at the shelf break in the Ross Sea, Pennell Coast shelf, Sulzberger Bay and Pine Island Bay represent erosion by debris-rich meltwater expelled when the ice grounded near the shelf break (Anderson, 1999). The fact that there is evidence for meltwater both landward and seaward of the mega-scale glacial lineations indicates that available meltwater was incorporated into the deforming till in the areas of mega-scale glacial lineations.

Bathymetry itself is a control on ice flow. Banks and adjacent troughs in the Ross Sea have primarily sedimentary substrates. However, ice flow over bank tops is interpreted to have been relatively slow, in contrast to the fast flow in the troughs (Shipp and others, 1999). A certain thickness of ice is required to create enough effective stress on the underlying sediments to initiate fast flow (Tulaczyk and others, $2000 \mathrm{a}, \mathrm{b})$. Therefore, once a trough has been formed, ice will consistently be thicker in those areas, and streaming will be concentrated in troughs and away from banks.

The shelf offshore of the Pennell Coast is one area where the zone of sedimentary substrate provides no evidence for a deforming bed, and there is no transition zone. There are a few linear, mounded features visible on the multibeam data in the area of sedimentary substrate. Because of their small scale, they are not interpreted to be mega-scale glacial lineations, but rather erosional grooves. Why there is no evidence for a deforming bed on the Pennell shelf is unclear; three possibilities are presented here. One reason may have to do with the width of the shelf. The Pennell study area has a narrow shelf with little sedimentary substrate; the maximum distance ice flowed over sedimentary substrate is about $35 \mathrm{~km}$. In other areas, such as Pine Island Bay (Fig. 6) and offshore of the Getz Ice Shelf (Fig. 5), the acceleration zone covers only a few tens of kilometers and forms right at the crystalline-sedimentary substrate transition. However, seaward of the transition zone there is over $300 \mathrm{~km}$ of sedimentary substrate in Pine Island Bay and at least $85 \mathrm{~km}$ in the Bakutis Coast area of Getz Ice Shelf. There may be a minimum distance over which the ice flows on sedimentary substrate to allow either for an increase in speed or else for geomorphic features to be formed. Alternatively, the dominant grain-size and associated porosity of the till may not be appropriate to hold the water needed to form deforming till. The Pennell Coast shelf sediments are dominated by volcanic sand, and the tills may be too sandy to develop into deformation till. Lastly, the Pennell Coast receives drainage from a small area of the Transantarctic Mountains and there may not have been enough ice feeding the system for ice-streaming at the scale recorded by megascale glacial lineations.

\section{IMPLIGATIONS}

Ice that is underlain by deformable till may be prone to fast retreat or to collapse (Engelhardt and others, 1990; MacAyeal, 1992). If this is true, is ice in places like Sulzberger Bay and the Pennell Coast inherently more stable than in places like the Ross Sea? Geomorphic features indicative of retreat, such as corrugation moraines, are present in the western Ross Sea (Shipp and others, 1999). These retreat features are evidence that the ice stayed in contact with its bed during retreat. Radiocarbon dates from the western Ross Sea also indicate a gradual retreat (Conway and others, 1999; Domack and others, 1999). There are no retreat features visible in any of the other study areas. This may indicate decoupling during ice-sheet retreat, but it may well be due to either a lack of sediment to form such features or incomplete data coverage. If the lack of retreat features is indicative of fast retreat, a potentially rapid retreat occurred in areas characterized by crystalline substrate and no deforming bed, such as Sulzberger Bay, and a slow and gradual retreat is indicated in the western Ross Sea, which had an extensive deforming bed. Do these data suggest that a deforming bed may not have led to instability? Tulaczyk and others (2000a, b) proposed that deformation of the subglacial bed may be a process that operates at endmembers of very fast or very slow flow, without taking place in the conditions between those two end-members. Thus, ice resting on a deforming bed may have an internally regulated mechanism by which fast flow may be stopped.

As ice advances and retreats across the shelf, it comes into contact with different substrates. This implies that, throughout a glacial cycle, ice behavior will be subject to different controls that should be included in models of ice behavior. Conditions for stability in the ice sheet also may change through multiple glacial cycles. The substrate and acceleration zones are not stationary through time. Throughout multiple glacial cycles, more and more erosion takes place, shifting the crystalline--sedimentary substrate contact farther seaward. This requires ice to be grounded farther onto the shelf in each cycle before it reaches the sedimentary substrate and is able to achieve fast flow.

\section{CONCLUSIONS}

This study provides the first documentation of the range of geomorphic features present on the Antarctic continental shelf and their correlation with substrate type. Where crystalline bedrock is the substrate, ice tended to follow the 
structural grain of the bedrock and carved deep troughs. Where ice flowed over relatively soft sedimentary strata, the direction of ice flow was more directly offshore. In these areas the signature of the ice consists of till deposition and mega-scale glacial lineations that formed in the deforming bed. Drumlins are the characteristic feature observed in the transition zone that spans the crystalline--sedimentary substrate. Ice is interpreted to have flowed relatively slowly in the area of crystalline substrates and relatively fast in the area of mega-scale glacial lineations. In this interpretation, drumlins would indicate a zone of acceleration. Because the presence of a deforming bed affects the rate at which ice can flow, the substrate below an ice sheet may also exert a fundamental control on the stability of that ice sheet.

\section{ACKNOWLEDGEMENTS}

This work was supported by U.S. National Science FoundationOffice of Polar Programs grant No. 9527876 to J. B. Anderson. The authors would like to thank the crew of the RV/IB Nathaniel B. Palmer and Antarctic Support Associates personnel for productive cruises. S. O'Hara provided invaluable support with the multibeam data. The staff at the Antarctic Research Facility at Florida State University provided assistance with the cores. We thank H. K. Campbell and A. Mosola for discussions. We also thank C. D. Clark, J. Taylor, an anonymous reviewer, and editor M.J. Hambrey for their helpful reviews of the manuscript.

\section{REFERENCES}

Alley, R. B. 1989. Water-pressure coupling of sliding and bed deformation: I. Water system. F. Glaciol., 35(119), 108-118.

Alley, R. B. 1991. Deforming-bed origin for southern Laurentide till sheets? 7. Glaciol., 37(125), 67-76.

Alley, R. B. and D. R. MacAyeal. 1994. Ice-rafted debris associated with binge/purge oscillations of the Laurentide ice sheet. Paleoceanography, 9(4), 503-511.

Alley, R. B., D. D. Blankenship, C. R. Bentley and S.T. Rooney. 1986. Deformation of till beneath Ice Stream B, West Antarctica. Nature, 322(6074), 57-59.

Alley, R. B., D. D. Blankenship, S. T. Rooney and C. R. Bentley. 1987. Till beneath Ice Stream B. 4. A coupled ice-till flow model. 7. Geophys. Res., 92(B9), 8931-8940.

Anandakrishnan, S., D. D. Blankenship, R. B. Alley and P. L. Stoffa. 1998. Influence of subglacial geology on the position of a West Antarctic ice stream from seismic observations. Nature, 394(6688), 62-65.

Anderson, J. B. 1999. Antarctic marine geology. Cambridge, etc., Cambridge University Press.

Anderson, J. B. and S. S. Shipp. 2001. Evolution of the West Antarctic ice sheet. In Alley, R. B. and R. A. Bindschadler, eds. The West Antarctic ice sheet: behavior and environment. Washington, DC, American Geophysical Union, 45-57. (Antarctic Research Series 77.)

Anderson, J. B., D. D. Kurtz, E.W. Domack and K. M. Balshaw. 1980. Glacial and glacial marine sediments of the Antarctic continental shelf. f. Geol., 88(4), 399-414.

Attig, J.W., D.M. Mickelson and L. Clayton. 1989. LateWisconsin landform distribution and glacier-bed conditions in Wisconsin. Sedimentary Geology, 62(3-4), 399-405.

Barker, P. F., A. Camerlenghi and G. Acton. 1998. Antarctic glacial history and sea-level change - Leg 178 samples Antarctic Peninsula margin sediments. Foint Ocean. Inst. Deep Earth Sampling, 24, 7-10.

Bart, P. J. and J. B. Anderson. 1995. Seismic record of glacial events affecting the Pacific margin of the northwestern Antarctic Peninsula. In Cooper, A. K., P. F. Barker and G. Brancolini, eds. Geology and seismic stratigraphy of the Antarctic margin 1. Washington, DC, American Geophysical Union, 74-95. (Antarctic Research Series 68.)

Bart, P. J. and J. B. Anderson. 2000. Relative temporal stability of the Antarctic ice sheets during the late Neogene based on the minimum frequency of outer shelf grounding events. Earth Planet. Sci. Lett., 182, 259-272.

Bell, R. E. and 6 others. 1998. Influence of subglacial geology on the onset of a
West Antarctic ice stream from aerogeophysical observations. Nature, 394(6688), 58-62.

Benn, D. I. and D. J. A. Evans. 1998. Glaciers and glaciation. London, Arnold.

Bentley, C.R. 1987. Antarctic ice streams: a review. F. Geophys. Res., 92(B9), 8843-8858.

Bindschadler, R. and P. Vornberger. 1998. Changes in the West Antarctic ice sheet since 1963 from declassified satellite photography. Science, 279(5351), 689-692.

Blankenship, D. D., C. R. Bentley, S. T. Rooney and R.B. Alley. 1986. Seismic measurements reveal a saturated porous layer beneath an active Antarctic ice stream. Nature, 322(6074), 54-57.

Blankenship, D. D., C. R. Bentley, S. T. Rooney and R. B. Alley. 1987. Till beneath Ice Stream B. 1. Properties derived from seismic travel times. 7. Geophys. Res., 92(B9), 8903-8911.

Blankenship, D. D. and 9 others. 2001. Geologic controls on the initiation of rapid basal motion for West Antarctic ice streams: a geophysical perspective including new airborne radar sounding and laser altimetry results. In Alley, R. B. and R. A. Bindschadler, eds. The West Antarctic ice sheet: behavior and environment. Washington, DC, American Geophysical Union, 105-121. (Antarctic Research Series 77.)

Boulton, G. S. 1996. The origin of till sequences by subglacial sediment deformation beneath mid-latitude ice sheets. Ann. Glaciol., 22, 75-84.

Brake, C. F. and J. B. Anderson. 1983. The bathymetry of the North Victoria Land continental margin. Mar. Geod., 6(2), 139-147.

Canals, M., R. Urgeles and A. M. Calafat. 2000. Deep sea-floor evidence of past ice streams off the Antarctic Peninsula. Geology, 23(1), 31-34.

Carol, H. 1947. The formation of roches moutonnées. F. Glaciol., 1 (2), 57-59.

Cassidy, D. S. 1984. USCG Glacier Operation Deep Freeze 1982 and 1983. Sediment descriptions. Tallahassee, FL, Florida State University. Antarctic Research Facility. Sediment Research Laboratory. (Contribution 52.)

Clark, C. D. 1993. Mega-scale glacial lineations and cross-cutting ice-flow landforms. Earth Surf. Processes Landforms, 18(1), 1-29.

Clark, C. D. 1994. Large-scale ice moulding: a discussion of genesis and glaciological significance. Sedimentary Geology, 91(1-4), 253-268.

Clark, P. U. 1994. Unstable behavior of the Laurentide ice sheet over deforming sediment and its implications for climate change. Quat. Res., $41(1), 19-25$.

Conway, H., B. L. Hall, G. H. Denton, A. M. Gades and E. D. Waddington. 1999. Past and future grounding-line retreat of the West Antarctic ice sheet. Science, 286(5438), 280-283.

Denton, G. H. and T. J. Hughes. 1981. The last great ice sheets. New York, etc., John Wiley and Sons.

Domack, E.W. and 6 others. 1998. Late Quaternary sediment facies in Prydz Bay, East Antarctica and their relationship to glacial advance onto the continental shelf. Antarct. Sci., 10(3), 236-246.

Domack, E.W., E. K. Jacobson, S. S. Shipp and J. B. Anderson. 1999. Late Pleistocene-Holocene retreat of the West Antarctic ice-sheet system in the Ross Sea: Part 2 - sedimentologic and stratigraphic signature: geophysical results. Geol. Soc. Am. Bull., 111 (10), 1517-1536.

Dreimanis, A. 1989. Tills: their genetic terminology and classification. In Goldthwait, R. P. and C. L. Matsch, eds. Genetic classification of glacigenic deposits. Rotterdam, A. A. Balkema, 17-83.

Engelhardt, H. and B. Kamb. 1991. Antarctic Ice Stream B: conditions controlling its motion and interactions with the climate system. International Association of Hydrological Sciences Publication 208 (Symposium at St. Petersburg 1990 - Glaciers-Ocean-Atmosphere Interactions), 145-154.

Engelhardt, H., N. Humphrey, B. Kamb and M. Fahnestock. 1990. Physical conditions at the base of a fast moving Antarctic ice stream. Science, $248(4951), 57-59$.

Hart, J. K. and B. Smith. 1997. Subglacial deformation associated with fast ice flow, from Columbia Glacier, Alaska. Sedimentary Geology, 111(1-4), 177-197.

Hayes, D. E. and L. A. Frakes. 1975. General synthesis. Deep Sea Drilling Project 28. In Initial report of the Deep Sea Drilling Project 28. Washington, DC, U.S. Government Printing Office, 919-942.

Hughes, T. 1973. Is the West Antarctic ice sheet disintegrating? f. Geophys. Res., 78(33), 7884-7910.

Hughes, T. 1977. West Antarctic ice streams. Reviewes of Geophysics and Space Physics, 15(1), 1-46.

Kamb, B. 1991. Rheological nonlinearity and flow instability in the deforming bed mechanism of ice stream motion. F. Geophys. Res., 96 (B10), 16,585-16,595.

Kellogg, T. B. and D. E. Kellogg. 1987. Late Quaternary deglaciation of the Amundsen Sea: implications for ice sheet modelling. International Association of Hydrological Sciences Publication 170 (Symposium at Vancouver 1987 - The Physical Basis of Ice Sheet Modelling), 349-357.

Kennedy, D. S. and J. B. Anderson. 1989. Glacial-marine sedimentation and Quaternary glacial history of Marguerite Bay, Antarctic Peninsula. Quat. Res., 31, 255-276.

Licht, K. J. 1999. Investigations into the late Quaternary history of the Ross 
Sea, Antarctica. (Ph.D. thesis, University of Colorado, Boulder.)

Licht, K. J., A. E. Jennings, J. T. Andrews and K. M. Williams. 1996. Chronology of the late Wisconsin ice retreat from the western Ross Sea, Antarctica. Geology, 24(3), 223-226.

Lundqvist, J. 1989a. Glacigenic processes, deposits, and landforms. In Goldthwait, R. P. and C. L. Matsch, eds. Genetic classification of glacigenic deposits. Rotterdam, A. A. Balkema, 3-16.

Lundqvist, J. 1989b. Rogen (ribbed) moraine - identification and possible origin. Sedimentary Geology, 62(3-4), 281-292.

MacAyeal, D. R. 1992. Irregular oscillations of the West Antarctic ice sheet. Nature, 359(6390), 29-32.

MacAyeal, D. R. 1993. Binge/purge oscillations of the Laurentide ice sheet as a cause of the North Atlantic's Heinrich events. Paleoceanography, 8(6), $775-784$.

Marshall, S. J., G. K.C. Clarke, A. S. Dyke and D. A. Fisher. 1996. Geologic and topographic controls on fast flow in the Laurentide and Cordilleran ice sheets. F. Geophys. Res., 101 (B8), 17,827-17,839.

Menzies, J. 1979. A review of the literature on the formation and location of drumlins. Earth Sci. Rev., 14(4), 315-359.

Mickelson, D. M., L. Clayton, D. S. Fullerton and H.W. Borns, Jr. 1983. The Late Wisconsin glacial record of the Laurentide ice sheet in the United States. In Wright, H. E., Jr, ed. Late-Quaternary environments of the United States. Volume 1. Minneapolis, MN, University of Minnesota Press, 3-37. (The Late Pleistocene.)

O'Brien, P.E. and P.T. Harris. 1996. Patterns of glacial erosion and deposition in Prydz Bay and the past behaviour of the Lambert Glacier. Pap. Proc. R. Soc. Tasmania, 130(2), 79-85.

Patterson, C. J. 1998. Laurentide glacial landscapes: the role of ice streams. Geology, 26(7), 643-646.

Pope, P. G. and J. B. Anderson. 1992. Late Quaternary glacial history of the northern Antarctic Peninsula's western continental shelf: evidence from the marine record. In Elliot, D. H., ed. Contributions to Antarctic research III. Washington, DC, American Geophysical Union, 63-91. (Antarctic Research Series 57.)
Rignot, E. J. 1998. Fast recession of a West Antarctic glacier. Science, $281(5376), 549-551$.

Rooney, S.T., D. D. Blankenship, R. B. Alley and C. R. Bentley. 1987. Till beneath Ice Stream B.2. Structure and continuity. 7. Geophys. Res., 92(B9), 8913-8920.

Shabtaie, S. and C. R. Bentley. 1987. West Antarctic ice streams draining into the Ross Ice Shelf: configuration and mass balance. 7. Geophys. Res., 92(B2), 1311-1336. (Erratum: f. Geophys. Res., 92(B9), 1987, p. 9451.)

Shaw, J. 1988. Subglacial erosional marks, Wilton Creek, Ontario. Can. F. Earth Sci., 25(8), 1256-1267.

Shaw, J., D. Kvill and B. Rains. 1989. Drumlins and catastrophic subglacial floods. Sedimentary Geology, 62(3-4), 177-202.

Shipp, S. S., J. B. Anderson and E.W. Domack. 1999. Late PleistoceneHolocene retreat of the West Antarctic ice-sheet system in the Ross Sea: Part 1 - geophysical results. Geol. Soc. Am. Bull., 111(10), 1486-1516.

Smith, H. T. U. 1948. Giant glacial grooves in northwest Canada. Am. F. Sci., 246, 503-514

Stokes, C. R. and C. D. Clark. 1999. Geomorphological criteria for identifying Pleistocene ice streams. Ann. Glaciol., 28, 67-74.

Tulaczyk, S., B. Kamb, R. P. Scherer and H. F. Engelhardt. 1998. Sedimentary processes at the base of the West Antarctic ice stream: constraints from textural and compositional properties of subglacial debris. F. Sediment. Res., 68(3A), 487-496.

Tulaczyk, S. M., B. Kamb and H. F. Engelhardt. 2000a. Basal mechanics of Ice Stream B, West Antarctica. I. Till mechanics. 7. Geophys. Res., 105(B1), 463-481.

Tulaczyk, S. M., B. Kamb and H. F. Engelhardt. 2000b. Basal mechanics of Ice Stream B, West Antarctica. II. Undrained-plastic-bed model. 7. Geophys. Res., 105(Bl), 483-494.

Van der Wateren, F. M. 1995. Processes of glaciotectonism. In Menzies, J., ed. Modern glacial environments: processes, dynamics and sediments. Glacial environments. Vol. 1. Oxford, etc., Butterworth-Heinemann, 309-335.

Whillans, I. M., J. Bolzan and S. Shabtaie. 1987. Velocity of Ice Streams B and C, Antarctica. 7. Geophys. Res., 92(B9), 8895-8902.

MS received 2 October 2000 and accepted in revised form 4 June 2001 